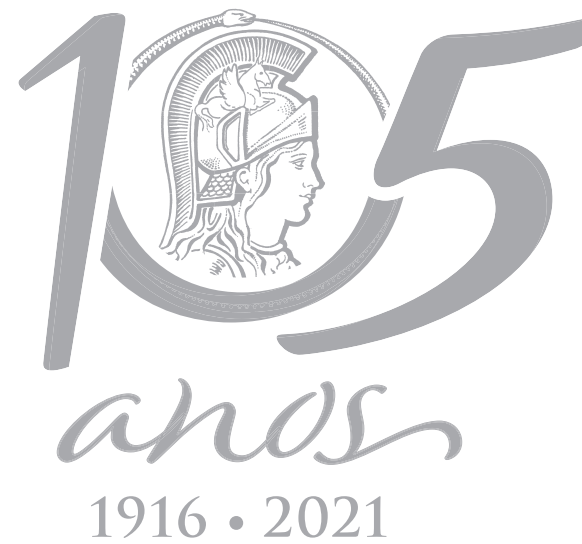

$1916 \cdot 2021$

\title{
Richness and distribution of the meliponine fauna (Hymenoptera: Apidae: Meliponini) in the State of Ceará, Brazil
}

\author{
JÂNIO A. FELIX \& BRENO M. FREITAS
}

\begin{abstract}
Meliponines, popularly known as stingless bees, present a great diversity of species widely distributed in tropical regions. Some species are rationally reared to obtain bee products like honey, pollen and wax, and most of them are important pollinators of the native and cultivated flora in Brazil. Nevertheless, stingless bees are little investigated in their natural range throughout the country, especially in NE Brazil. This work is the first comprehensive survey sampling stingless bee species throughout the state of Ceará investigating their occurrence and distribution in different phytoecological units. In this sense, the study evaluated the species richness; the distribution in the diverse types of vegetation and relief formations; and reviewed the list of species with occurrence already described and incorporated 20 new occurrences for Ceará, increasing the number of species reported to the state from 29 to 49. We also indicate rare species and those once common but presently threatened mainly due to habitat loss, demonstrating the need of conservation efforts and potential for sustainable exploitation of these bee species and their habitats through meliponiculture. It also shed light in the potential richness of stingless bee species in NE Brazil.
\end{abstract}

Key words: bee diversity, bee conservation, meliponiculture, stingless bees.

\section{INTRODUCTION}

Meliponines (Hymenoptera: Apidae, Apinae, Meliponini) are popularly known as stingless bees because they cannot sting. These bees are widely distributed on the planet, especially in the Tropical and Subtropical Zone, with greater richness in the Neotropical region (Roubik 1989). Many of these bee species can be managed to obtain products such as honey, pollen, wax and services such as pollination (Contrera et al. 2011, Bomfim et al. 2014).

The rational breeding of these bees is called meliponiculture, and has been considered as a potential activity for sustainable development, since it can help improve the income and quality of life of many rural families by selling and consuming the products obtained (Jaffé et al. 2015, Magalhães \& Venturieri 2010). In addition, meliponines provide a critical ecosystem service through pollination of native and/or cultivated plants. They are responsible for pollination of up to $90 \%$ native plant species in ecosystems such as the Atlantic forest, contributing to the maintenance of biodiversity in natural ecosystems (Imperatriz-Fonseca et al. 2012).

However, a general decline in bee populations around the world, including Brazil, have been reported (IPBES 2016, BPBES/REBIPP 2019). Several factors, including climate change, diseases, invasive species, pesticide misuse, deforestation and increased urbanization, are reported as responsible for the decline of bees, and initiatives to diminish this trend 
are urgently needed (Potts et al. 2010, IPBES 2016). Studies on the occurrence and diversity of bee species can be used as a basis for environmental conservation and the scarcity of information on the biodiversity of this group of insects is pointed out as one of the obstacle for the conservation of native species in the neotropical region (Freitas et al. 2009).

In addition to this, the growth and diffusion of meliponiculture in Brazil has led to the transport of stingless bee species between states and regions out of their native range, despite federal legislation ruling against the trade and transportation of stingless bees to regions with different environmental characteristics and outside the region of natural occurrence of each species, as provided in CONAMA Resolution 346/2004 (Brasil 2004). Information on the natural occurrence and distribution of the species can help the stingless beekeepers to practice a more sustainable and ecologically correct activity that does not pose risks to local native populations of meliponines with an indiscriminate transportation of colonies (Vollet Neto et al. 2018).

The meliponine fauna of the state is still poorly sampled and there is confusion as to the number of species native to Ceará. While studies conducted by Ducke (1907, 1908, 1910), Rocha (1950) and Gonçalves (1973) resulted in a total diversity of 31 species, Camargo and Pedro (2013) and later Pedro (2014) reduced those numbers to 29 and 25 species, respectively. These discrepancies are due to corrections in the identification of species and their actual occurrence in the state. However, there are indications that the richness of species of meliponines in Ceará is greater than the officially registered number, both because the majority of the surveys have used occasional samplings, and the record of new occurrences and new species in recent studies. In the first two decades of this century, there was the first report of occurrence of Melipona quinquefasciata in the Northeastern region (Lima-Verde \& Freitas 2002); a detailed book chapter reviewing Ducke's studies in Ceará, including species of meliponines (Westerkamp et al. 2007); the flora survey and associated meliponine species in the Baturite Massif performed by Lima-Verde et al. (2014) and Lima-Verde et al. (2020), the first occurrence of Lestrimellita rufa (Mascena et al. 2017), and the report of two new species, Scaura cearensis (Nogueira et al. 2019a) and Paratrigona intermedia (Oliveira et al. 2020). In this context, this study aimed to carry out a comprehensive survey investigating the occurrence and distribution of meliponines throughout the State of Ceará, in order to gather information that contributes to the preservation of species and the diversification of the bee species kept in the meliponaries.

\section{MATERIALS AND METHODS}

\section{Study area}

According to the map of biomes of Brazil (IBGE 2004), the State of Ceará presents a single biome, the caatinga, in all its territory. However, a detailed examination of the landscape, relief formations and environmental characteristics of different regions of the state, shows that this does not represent all the phytoecological diversity present in Ceará (Moro et al. 2015). In this study, instead of the political division, we separated the sampling regions into Phytoecological Units, since this can evidence differences in the distribution of species according to the climatic and environmental diversity of the territory of the State of Ceará.

The study was carried out between March 2013 and July 2014. We collected data in 122 sampling sites (Figure 1) distributed across 52 municipalities in Ceará State, Northeastern 


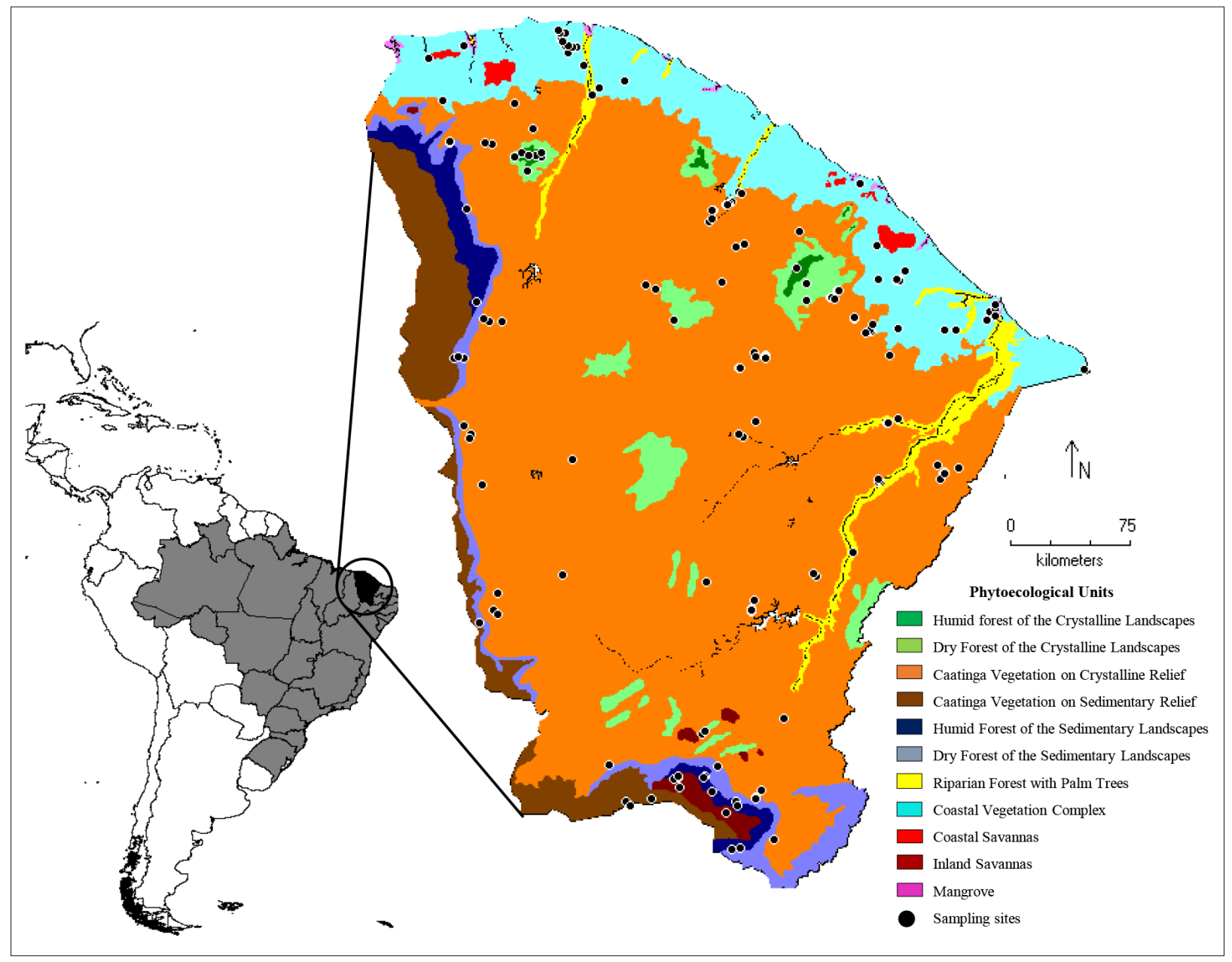

Figure 1. Map of the eleven Phytoecological Units and sampling sites of meliponines (Hymenoptera: Apidae: Meliponini) in the State of Ceará in 2013 and 2014. Adapted from Moro et al. (2015).

region of Brazil. The state's territory encompasses different geomorphological units, from sedimentary sandy terrains to crystalline rock outcrops. The main geomorphological sections of the state are: Sedimentary Reliefs Forms - Coastal flatlands, Fluvial Plains, Inland Sedimentary Plateaus (highlands); Crystalline Reliefs Forms - Sertaneja Depression lowlands, Residual Massif highlands and inselbergs. A number of vegetation types, including the Coastal Vegetation Complex, Coastal Savannas, Mangroves, Riparian Forest with Palm Trees, Humid Forest of the Sedimentary Landscapes, Dry Forest of the Sedimentary Landscapes,
Caatinga Vegetation on Sedimentary Relief, Inland Savannas, Caatinga Vegetation on Crystalline Relief ${ }_{2}$ Humid forest in the crystalline landscapes, Dry forest in the crystalline landscapes (Moro et al. 2015). Most of the territory, about $68 \%$, is formed by Caatinga Vegetation of Crystalline Relief (Moro et al. 2015). According to the climatic classification of Thornthwaite (1948), the State of Ceará presents four types of climate: E - Arid, D - Semi-arid, C1 - Dry Subhumid and C2 - Moist Subhumid, with the semi-arid climate predominating in approximately $85 \%$ state territory. 


\section{Bee sampling, mounting and labeling}

Samplings were carried out in eight phytoecological units with the exception of Coastal Savannas, Riparian Forest with Palm Trees and Mangrove. Bees were collected by three methods: i. manually in meliponaries established in each region, but only from colonies originating from natural sites close to the meliponaries to avoid possible errors with meliponines introduced from other phytoecological units or from other states; ii. in natural nests, in hollow or dry trunks, termite nests, soil and wooden stakes, for example; iii. sweeping flowers in the field with an entomological net (Sakagami et al. 1967). The individuals sampled were killed in a killing jar with Ethyl Acetate, then mounted and oven dried at $42^{\circ} \mathrm{C}$ for approximately 48 hours. After drying, they were labeled and sent for identification by taxonomists.

In addition, we performed a literature review on studies dealing with the natural occurrence of meliponines and presented an updated list of the occurrence of meliponines for the State of Ceará (Ducke 1908, 19010, Gonçalves 1973, Westerkamp et al. 2007, Lima-Verde 2011, Pedro 2014, Mascena et al. 2017, Madella-Auricchio 2018, Nogueira et al. 2019a, Oliveira et al. 2020).

\section{RESULTS}

We identified the natural occurrence of 14 genera that comprise 34 species of meliponines in the State of Ceará. Besides these, we also collected other two species that were introduced from other states. The genera with the highest number of species were Melipona Illiger, 1806 and Trigona Jurine, 1807 with six species each, followed by Partamona Schwarz, 1939 (5 species), Scaptotrigona Moure, 1942 (4 species), Frieseomelitta Ihering, 1912 (3 species), Nannotrigona Cockerell, 1922 (2 species),
Cephalotrigona Schwarz, 1940, Lestrimelitta Friese 1903, Oxytrigona Cockerell, 1917, Paratrigona Schwarz, 1938, Plebeia Schwarz, 1938, Scaura Schwarz, 1938, Tetragonisca Moure, 1946 and Trigonisca Moure, 1950 with only one species each (Table I).

Fifty samples were taken in natural nests, 35 samples in flowers and 316 samples in hives in the meliponaries. The number of individuals in each sample collected varied according to factors such as the size of the colony population; the consent of the stingless beekeepers; the difficulty of access to nests and individuals; the defense system of each species; and the number of individuals present in the flowers.

Of the total species collected, $70.5 \%$ (24) were found in beehives in the meliponaries, and $29.5 \%$ (10) of the species were only found in nature, either in a natural nest or on flowers. Among the species found in the meliponaries, some were very frequent, such as jandaira (Melipona subnitida Ducke 1910) and jati (Plebeia cf. flavocincta (Cockerell 1912)). Other species, such as Melipona asilvai Moure 1971, Frieseomelitta doederleini (Friese 1900) and Scaptotrigona spp., although also present in meliponaries, were less frequent and when present, in smaller number of hives. Finally, species such as Trigona pallens (Fabricius 1798) and Melipona (Melipona) mandacaia Smith 1863, although they have also been collected in hives, they are rare in meliponaries of Ceará.

After the identification of the specimens, we observed that five species had not been previously recorded as natural occurrences for state of Ceará, which were Cephalotrigona aff. femorata (Smith, 1854); Frieseomelitta languida (Moure 1990); Melipona (Michmelia) mondury Smith, 1863; Scaptotrigona aff. depilis (Moure 1942) and Trigonisca aff. extrema (Albuquerque \& Camargo, 2007). In addition to these new records, we also collected three species that 
Table I. Richness of meliponine species found in the State of Ceará, Brazil, in 2013 and 2014.

\begin{tabular}{|c|c|c|c|c|}
\hline Meliponine Species & $\begin{array}{c}\text { Vernacular } \\
\text { name * }\end{array}$ & $\begin{array}{c}\text { Number of } \\
\text { samples }\end{array}$ & $\begin{array}{l}\text { Number of } \\
\text { individuals }\end{array}$ & $\begin{array}{l}\text { Sampling } \\
\text { method }\end{array}$ \\
\hline Cephalotrigona aff. femorata (Smith, 1854) & Mombucão & 2 & 18 & Col./NN \\
\hline Frieseomelitta doederleini (Friese, 1900) & $\begin{array}{l}\text { Moça branca, } \\
\text { abelha branca }\end{array}$ & 14 & 150 & Col./NN/EN \\
\hline Frieseomelitta languida (Moure, 1990) & Mocinha preta & 2 & 12 & NN \\
\hline Frieseomelitta varia (Lepeletier, 1836) & $\begin{array}{c}\text { Breu, } \\
\text { zamboque, } \\
\text { marmelada }\end{array}$ & 12 & 56 & Col./NN \\
\hline Lestrimelitta tropica (Marchi \& Melo, 2006) & Limão & 1 & 10 & NN \\
\hline Melipona (Eomelipona) asilvai Moure, 1971 & Munduri, rajada & 3 & 14 & Col. NN \\
\hline Melipona (Michmelia) flavolineata Friese, 1900 & Uruçu amarelo & 2 & 13 & Col. \\
\hline Melipona (Melipona) mandacaia Smith, 1863 & Mandaçaia & 2 & 21 & Col./NN \\
\hline Melipona (Michmelia) mondury Smith, 1863 & Uruçu amarelo & 6 & 81 & Col. \\
\hline $\begin{array}{c}\text { Melipona (Melikerria) quinquefasciata Lepeletier, } \\
\qquad 1836\end{array}$ & Uruçu do chão & 3 & 13 & Col./NN \\
\hline Melipona (Melipona) subnitida Ducke, 1910 & Jandaíra & 202 & 1526 & Col./NN \\
\hline Nannotrigona sp. 1 Cockerell, 1922 & Iraí, camuengo & 2 & 24 & Col. \\
\hline Nannotrigona sp. 2 Cockerell, 1922 & Iraí & 4 & 21 & Col. \\
\hline Oxytrigona tataira (Smith, 1863) & $\begin{array}{c}\text { Tataira, caga- } \\
\text { fogo }\end{array}$ & 3 & 16 & Col. NN \\
\hline Partamona ailyae (Camargo, 1980) & Mombuca & 3 & 34 & NN \\
\hline Partamona aff. cupira (Smith, 1863) & $\begin{array}{c}\text { Cupira, boca- } \\
\text { de-sapo }\end{array}$ & 9 & 61 & Col./NN \\
\hline Partamona aff. rustica (Pedro \& Camargo, 2003) & Cupira & 1 & 6 & NN \\
\hline Partamona aff. seridoensis Pedro \& Camargo, 2003 & Cupira & 13 & 115 & Col./NN \\
\hline Partamona sp. Pedro \& Camargo, 2003 & Cupira & 1 & 5 & NN \\
\hline Paratrigona lineata (Lepeletier, 1836) & $\begin{array}{l}\text { Jataí da terra, } \\
\text { jati do chão }\end{array}$ & 1 & 7 & NN \\
\hline Plebeia cf. flavocincta (Cockerell, 1912) & $\begin{array}{l}\text { Jati, mosquito, } \\
\text { mirim }\end{array}$ & 26 & 154 & Col., NN, EN \\
\hline Scaptotrigona sp. nov. 1 Oliveira \& Jesus, in litt. & Canudo & 14 & 96 & Col. \\
\hline Scaptotrigona sp. nov. 2 Oliveira \& Jesus, in litt. & Tubiba & 3 & 38 & Col. \\
\hline Scaptotrigona aff. depilis (Moure, 1942) & $\begin{array}{l}\text { Canudo, } \\
\text { mandaguari }\end{array}$ & 19 & 113 & Col. \\
\hline Scaptotrigona postica (Latreille, 1807) & Canudo & 14 & 68 & Col. \\
\hline Scaura sp. nov. Nogueira, in litt. & Pegoncito & 1 & 4 & NN \\
\hline Trigona aff. fuscipennis (Friese, 1900) & $\begin{array}{l}\text { Sanharó, } \\
\text { sanharão }\end{array}$ & 5 & 40 & NN \\
\hline
\end{tabular}


Table I. Continuation

\begin{tabular}{|c|c|c|c|c|}
\hline Trigona spinipes (Fabricius, 1793) & Arapuá, irapuá & 10 & 64 & NN/EN \\
\hline Trigona pallens (Fabricius, 1798) & Olho de vidro & 2 & 12 & Col./ EN \\
\hline Trigona recursa (Smith, 1863) & $\begin{array}{c}\text { Vamos embora, } \\
\text { feiticeira, purga }\end{array}$ & 5 & 51 & NN \\
\hline Trigona guianae (Cockerell, 1910) & $\begin{array}{c}\text { Bunda de vaca, } \\
\text { cú de vaca }\end{array}$ & 4 & 28 & NN, EN \\
\hline Trigona sp. Jurine, 1807 & $\begin{array}{c}\text { Bunda de vaca, } \\
\text { cú de vaca }\end{array}$ & 1 & 12 & EN \\
\hline Tetragonisca angustula (Latreille, 1811) & Jataí & 2 & 10 & Col., NN \\
\hline Trigonisca aff. extrema (Albuquerque \& Camargo, & $\begin{array}{c}\text { Lambe olhos } \\
\text { 2007) }\end{array}$ & 2 & 8 & NN, EN \\
\hline Melipona fasciculata (Smith, 1854)** & Tiúba & 3 & 28 & Col. \\
\hline Melipona scutellaris (Latreille, 1811)** & $\begin{array}{c}\text { Uruçu } \\
\text { nordestina }\end{array}$ & 4 & 40 & Col. \\
\hline Total & & 401 & 2969 & \\
\hline
\end{tabular}

*Source: Information from stingless beekeepers of the State of Ceará and Moure catalog (Camargo \& Pedro 2013).

** Species introduced from another State.

Sampling method: Col.= Direct collection in colonies in meliponaries; $N N=$ Collection in natural nest; EN = Collection using an entomological net on flowers.

were being considered as new to science (Scaptotrigona sp. nov. 1 Oliveira \& Jesus, in litt.; Scaptotrigona sp. nov. 2 Oliveira \& Jesus, in litt.; Scaura sp. nov. Nogueira in litt.), the latter being confirmed later as a new species $S$. cearensis (Nogueira et al 2019a).

Only two species, Plebeia cf. flavocincta and Trigona spinipes, were found in all eight phytoecological units listed in table II. Melipona flavolineata, Cephalotrigona aff. femorata, Trigona guianae, Nannotrigona sp. 1 and sp. 2 were only found in the Humid forest of the Crystalline Landscapes and Dry Forest of the Crystalline Landscapes, which are present in the Residual Massif highlands of the State. Melipona mondury and Trigona recursa were found in the Humid Forest of the Sedimentary Landscapes and Dry Forest of the Sedimentary Landscapes. Other species such as Partamona sp., Scaura cearensis, Trigona sp., Tetragonisca angustula and Melipona mandacaia were collected in only one phytoecological unit each (Table II).
Humid forest of the Crystalline Landscapes was the phytoecological unit with the largest number of genera (10) and species (19), followed by the Dry Forest of the Crystalline Landscapes (eight genera and 18 species), Humid Forest of the Sedimentary Landscapes and Dry Forest of the Sedimentary Landscapes, both with (seven genera) (14 species), Caatinga Vegetation on Crystalline Relief (seven genera and 13 species), coastal vegetation complex (seven genera and 10 species), Caatinga Vegetation on Sedimentary Relief (four genera and seven species) and Inland Savannas (four genera and six species) (Figures 2 and 3).

Up to now, studies on the occurrence of meliponines in Ceará presented richness varying between 18 and 29 species and the number of genera between 11 and 15 (Table III). Here, we present an extended and updated list adding our results to the findings of older (Ducke 1908, 1910, Gonçalves 1973, Westerkamp et al. 2007, LimaVerde 2011, Pedro 2014) and more recent studies 
Table II. Occurrence of meliponine species in eight phytoecological Units of the State of Ceará in 2013 and 2014.

\begin{tabular}{|c|c|c|c|c|c|c|c|c|}
\hline \multirow{2}{*}{ Meliponine Species } & \multicolumn{6}{|c|}{ Phytoecological Units } & \multirow[b]{2}{*}{ DFS } & \multirow[b]{2}{*}{ IS } \\
\hline & CVC & DFC & HFC & CCR & CVS & HFS & & \\
\hline Cephalotrigona aff. femorata & & $x$ & $x$ & & & & & \\
\hline Frieseomelitta doederleini & $x$ & $x$ & & $x$ & $x$ & & $x$ & \\
\hline Frieseomelitta languida & & $x$ & & & & & $x$ & \\
\hline Frieseomelitta varia & $x$ & $x$ & & $x$ & $x$ & $x$ & $x$ & \\
\hline Lestrimelitta tropica & & & $x$ & & & & & \\
\hline Melipona (Eomelipona) asilvai & & & & $x$ & $x$ & & & \\
\hline Melipona (Michmelia) flavolineata & & $x$ & $x$ & & & & & \\
\hline Melipona (Melipona) mandacaia & & & & $x$ & & & & \\
\hline Melipona (Michmelia) mondury & & & & & & $x$ & $x$ & \\
\hline Melipona quinquefasciata & & & & & $x$ & $x$ & & $x$ \\
\hline Melipona (Melipona) subnitida & $x$ & $x$ & & $x$ & $x$ & & $x$ & \\
\hline Nannotrigona sp. 1 & & $x$ & $x$ & & & & & \\
\hline Nannotrigona sp. 2 & & $x$ & $x$ & & & & & \\
\hline Oxytrigona tataira & & & $x$ & & & $x$ & & \\
\hline Partamona ailyae & & $x$ & $x$ & & & $x$ & & \\
\hline Partamona aff. cupira & & $x$ & $x$ & $x$ & & & & \\
\hline Partamona aff. rustica & & & $x$ & & & & & \\
\hline Partamona aff. seridoenses & $x$ & $x$ & $x$ & $x$ & & & & \\
\hline Partamona sp. & & & & $x$ & & & & \\
\hline Paratrigona lineata & & & & & & & $x$ & \\
\hline Plebeia cf. flavocincta & $x$ & $x$ & $x$ & $x$ & $x$ & $x$ & $x$ & $x$ \\
\hline Scaptotrigona sp. nov. 1 & $x$ & $x$ & $x$ & $x$ & & $x$ & & $x$ \\
\hline Scaptotrigona sp. nov. 2 & & & $x$ & & & $x$ & $x$ & \\
\hline Scaptotrigona aff. depilis & $x$ & $x$ & $x$ & & & $x$ & $x$ & $x$ \\
\hline Scaptotrigona postica & & $x$ & $x$ & & & $x$ & $x$ & $x$ \\
\hline Scaura sp. nov. Nogueira, in litt. & & & $x$ & & & & & \\
\hline Trigona aff. fuscipennis & $x$ & $x$ & & $x$ & & & $x$ & \\
\hline Trigona spinipes & $x$ & $x$ & $x$ & $x$ & $x$ & $x$ & $x$ & $x$ \\
\hline Trigona pallens & & & $x$ & & & $x$ & & \\
\hline Trigona recursa & & & & & & $x$ & $x$ & \\
\hline Trigona guianae & & $x$ & $x$ & & & & & \\
\hline Trigona sp. & & & & & & $x$ & & \\
\hline Tetragonisca angustula & & & & & & $x$ & & \\
\hline Trigonisca aff. extrema & $x$ & & & $x$ & & & & \\
\hline Melipona fasciculata ** & $x$ & & & & & & & \\
\hline Melipona scutellaris ** & $x$ & & $x$ & & & & & $x$ \\
\hline
\end{tabular}

Phytoecological Units: CVC - Coastal Vegetation Complex; DFC - Dry Forest of the Crystalline Landscapes; HFC - Humid forest of the Crystalline Landscapes; CCR- Caatinga Vegetation on Crystalline Relief; CVS - Caatinga Vegetation on Sedimentary Relief; HFS - Humid Forest of the Sedimentary Landscapes; DFS- Dry Forest of the Sedimentary Landscapes; IS - Inland Savannas.

** Species introduced from other States. 
(Mascena et al. 2017, Nogueira et al. 2019a, Oliveira et al. 2020), elevating these figures to a total of 49 species distributed in 18 genera (Table IV). However, it is worthy to stress that 49 species is a conservative figure once we did not include in the count a species reported as Plebeia emerina by Ducke (1910) and later restated as Plebeia sp. in Westerkamp et al (2007) because we had no access to the specimens collected to know whether this is a distinct species or not to other Plebeia species occurring in Ceará. We also did not take in account for the total number of stingless bee species in Ceará two potential new species collected in our study, Scaptotrigona sp. nov. 1 Oliveira \& Jesus, in litt.; Scaptotrigona sp. nov. 2 Oliveira \& Jesus, in litt, because they are not valid yet as new species. Therefore, the richness of meliponines in the state of Ceará can rise up to 52 species.

\section{DISCUSSION}

This work was the first comprehensive survey of meliponines in the state of Ceará. Not surprisingly, the number of species found indicates a high richness of stingless bees, sampling and identifying many more species than already reported in other scattered surveys of this group of bees in the state (Ducke 1908, 1910, Gonçalves 1973, Westerkamp et al. 2007). Although Trigona and Melipona were dominant in species richness, 12 other genera were also observed, which shows the varied presence of meliponine groups in the studied regions. Despite Ceará shows poorer in species diversity than the Amazonian biome (Kerr et al. 2001), it bears similar richness to the Cerrado region and the Cerrado-Amazon transition zone, in the State of Tocantins (Costa-Neto et al. 2016), and higher number of bee species than its neighboring

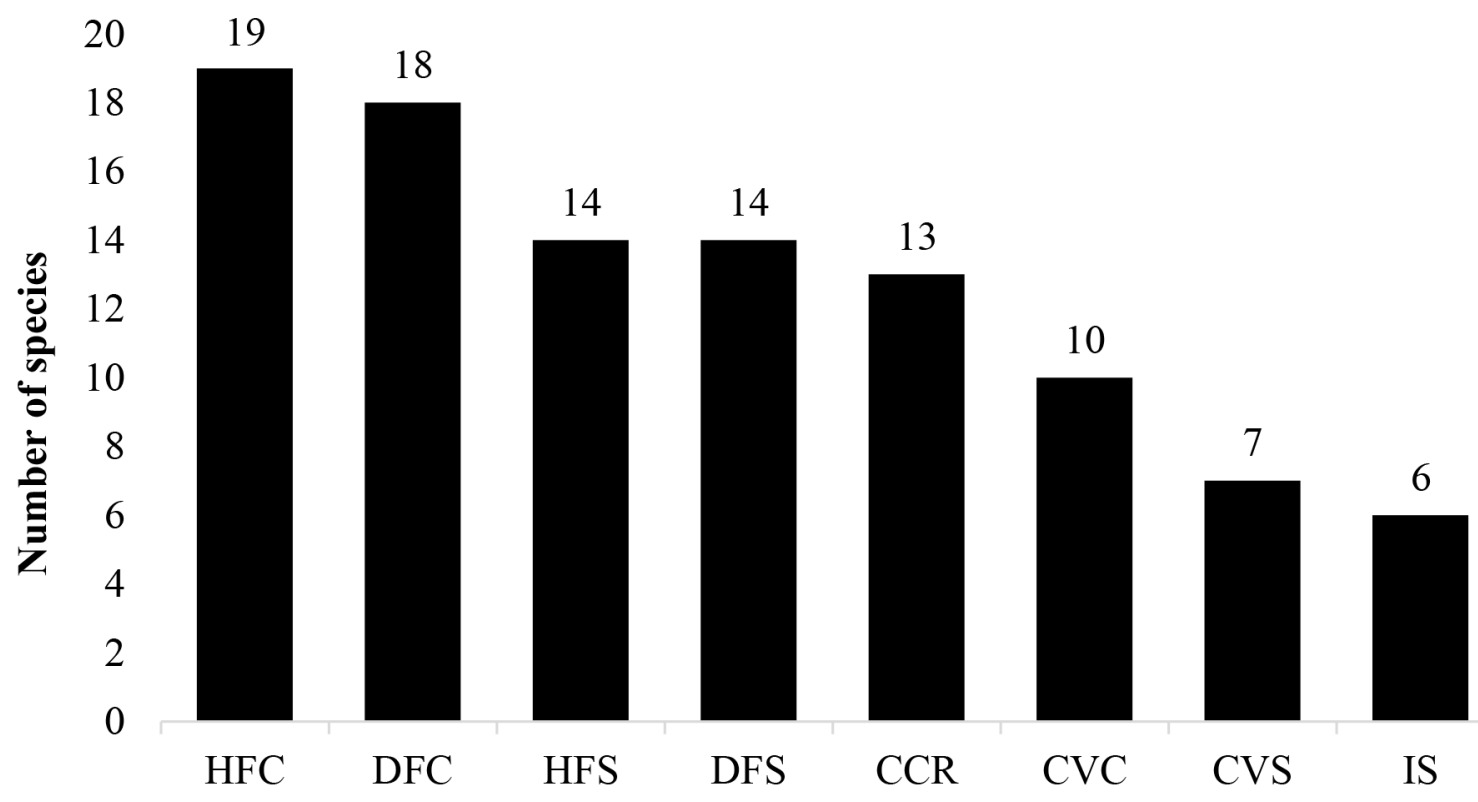

\section{Phytoecological Units}

Figure 2. Representation of the number of meliponine species in eight phytoecological unit of the State of Ceará in 2013 and 2014. Phytoecological Units: HFC - Humid forest of the Crystalline Landscapes; DFC - Dry Forest of the Crystalline Landscapes; HFS - Humid Forest of the Sedimentary Landscapes; DFS- Dry Forest of the Sedimentary Landscapes; CCR- Caatinga Vegetation on Crystalline Relief; CVC - Coastal Vegetation Complex; CVS - Caatinga Vegetation on Sedimentary Relief; IS - Inland Savannas. 
State of Rio Grande do Norte (Carvalho \& Zanella 2017).

The number of samples collected in this study was only possible with the help of stingless beekeepers, since the fragmentation of habitats promoted by the strong deforestation in many regions of the state made it in many cases easier to find colonies in meliponaries than in wild nests. Also, the elimination of trees of larger trunk and stem diameters or that naturally provide cavities that serve as a nesting substrate for most meliponine species affects the survival of natural populations (Venturieri 2009). These may be important points to explain the difficulty to find wild nests of many stingless bee species in Ceará. Indeed, we found twice as many species in hives as only in nature. However, long-term studies in Panama and Ecuador with many years of study and collecting have found that the total species of meliponines comes out to be $50 \%$ more than what was originally thought
(Roubik 2018, Roubik \& Moreno Patiño 2018, Vit et al. 2018). This seems to indicate that beekeepers usually focus on those species which respond well to being kept in hives, produce more honey or are not aggressive and do not know much about many species that live, or once lived, near them. Therefore, a long-term study may find even more meliponine species in Ceará.

The richness of species (24) found in meliponaries evidences the potential for diversification of meliponiculture in the state, although the activity is still mainly based on the breeding of M. subnitida (Felix 2015). This is probably due to its wide distribution, good demand and value added to its honey. The higher number of species with the possibility of being bred and managed tends to diversify the number of products obtained from the activity, which can even improve the income and/or expand market niches for the stingless beekeepers (Jaffé et al. 2015). Other species which beekeeping

12

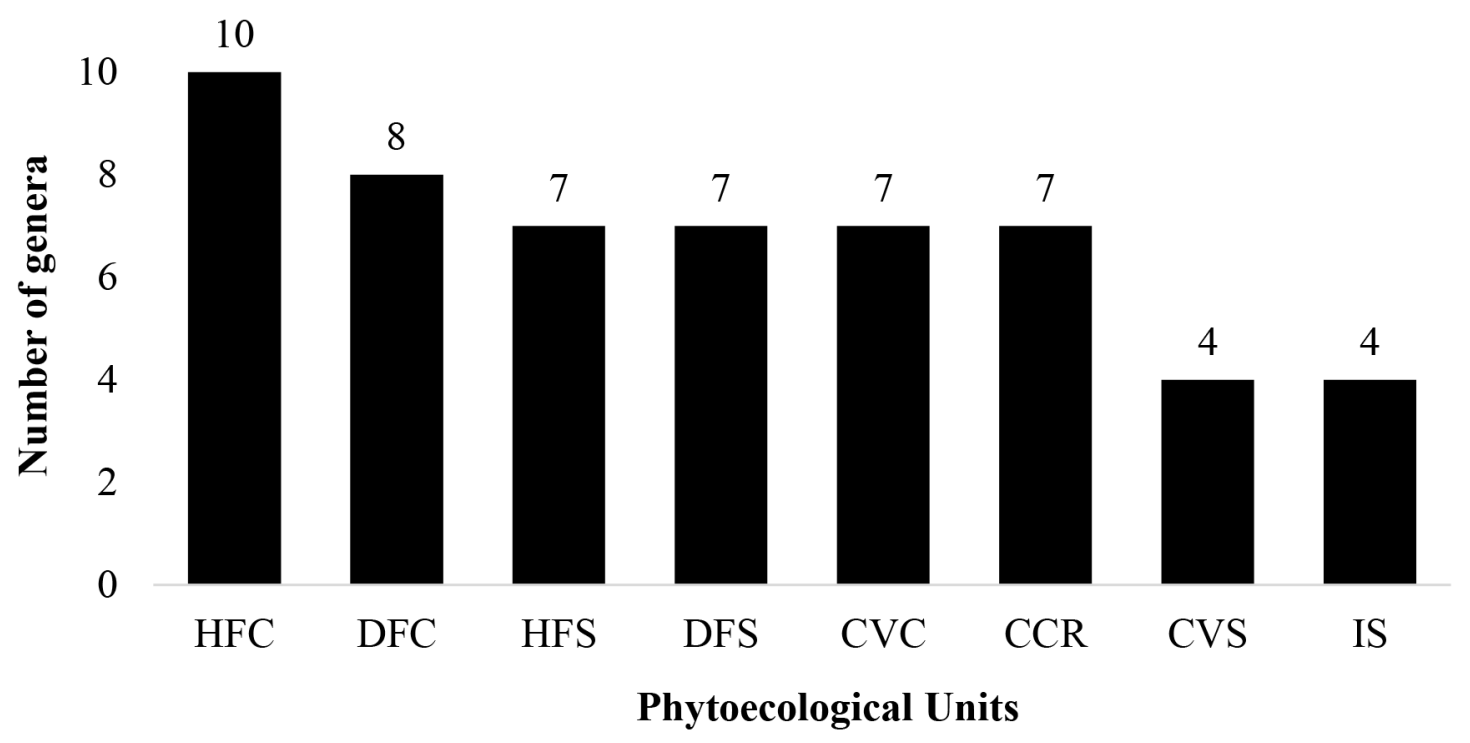

Figure 3. Representation of the abundance of meliponine genera in eight phytoecological units of the State of Ceará in 2013 and 2014. Phytoecological Units: HFC - Humid forest of the Crystalline Landscapes; DFC - Dry Forest of the Crystalline Landscapes; HFS - Humid Forest of the Sedimentary Landscapes; DFSDry Forest of the Sedimentary Landscapes; CCR- Caatinga Vegetation on Crystalline Relief; CVC - Coastal Vegetation Complex; CVS - Caatinga Vegetation on Sedimentary Relief; IS - Inland Savannas. 
potential is already recognized in Brazil, such as F. doederleini, M. asilvai and Scaptotrigona spp. (Yamamoto et al. 2007, Souza et al. 2009), are still poorly explored in the state but their breeding could help diversify the meliponine production in Ceará.

Although we find many species in meliponaries of Ceará, some are extremely rare as is the case of T. pallens and M. mandacaia. The latter species, once considered relatively common in several regions of the state and reported as abundant in some regions such as Cariri and Araripe (Gonçalves 1973), has nowadays become rare not only in meliponaries but also in nature, indicating a strong populational decline with an imminent risk of local extinction.

Despite the previous occurrence surveys in Ceará, we found five new occurrences for the state (C. aff. femorata; F. languida; M. mondury; $S$. aff. depilis and $T$. aff. extrema). This reinforces the importance of this study for the knowledge of the local bee fauna and can help both the meliponiculture and the preservation and conservation of these species, since the lack of knowledge about the richness, diversity and distribution of bees has been pointed out as one of the problems for the conservation of species native to the Neotropical region (Freitas et al. 2009). The three species (Scaptotrigona sp. nov. 1 Oliveira \& Jesus, in litt.; Scaptotrigona sp. nov. 2 Oliveira \& Jesus, in litt.; Scaura cearensis Nogueira et al 2019a) found in this study and being described as new species, as well as the recently described new species Paratrigona intermedia (Oliveira et al 2020), reinforces the relevance of these surveys and further evidence the richness of the ecosystems of the State of Ceará. The discovery of new species makes it possible to initiate studies on biology, behavior and management for both conservation and beekeeping purposes.

The occurrence of $T$. pallens, C. aff. femorata and T. aff. extrema, bee species typical of the Amazon biome, and also bee species typical of the Atlantic forest, such as M. mondury, may be explained by ancient climatic variations in the Pleistocene that allowed the merge of the Amazon biome and Atlantic forest in the Brazilian Northeast. Later, following numerous climatic events, such as glaciations, orogenic processes and erosions, there were still remains of altitude humid areas that maintained characteristics and elements as plant species common to the biomes of Amazon Forest and Atlantic forest that allowed the survival of these bee species in such ecosystems although surrounded by

Table III. Number of genera and species cited in the main studies and in the present study on the occurrence of meliponines for the State of Ceará.

\begin{tabular}{|c|c|c|c|c|}
\hline Source & Number of genera & Unidentified species & Species identified & Total species \\
\hline Ducke 1908, 1910 & 15 & 1 & 21 & 22 \\
\hline Gonçalves 1973 & 11 & 5 & 19 & 24 \\
\hline Westerkamp et al. 2007 & 11 & 0 & 18 & 18 \\
\hline Lima-Verde 2011 & 11 & 7 & 13 & 20 \\
\hline Camargo \& Pedro 2013 & 14 & 0 & 29 & 29 \\
\hline Pedro 2014 & 12 & 0 & 25 & 25 \\
\hline Present study & 14 & 7 & 27 & 34 \\
\hline
\end{tabular}


Caatinga or Cerrado (Andrade-Lima 1982, Santos et al. 2007, Ribeiro-Silva et al. 2012).

In the case of the species Scaura cearensis, it was found only in the Meruoca mountain range, a formation with an altitude of 700 - 900 meters and characteristics of wet forest, surrounded by the Sertaneja Depression lowlands (Caatinga Vegetation on Crystalline Relief) on all sides, that may have acted as a natural barrier causing the geographic isolation of this group of bees of the genus Scaura, which for a long time under the environmental characteristics of this region allowed for speciation (Nogueira et al. 2019b). Residual massifs such as those of the Meruoca and the Baturité mountain ranges originated from orogenic and erosion processes can function as refuges and also allow the emergence of new animal species (Mantovani 2007, Brandão \& Freitas 2014).

Regarding the distribution of $T$. spinipes and Plebeia aff. flavocincta, these bees were found in all the phytoecological units sampled, showing a wide geographic plasticity and adaptability. Trigona spinipes is recognized for being able to adapt to different types of natural and altered landscapes (agricultural or urban). This success in the expansion and colonization of several areas is probably due to its general foraging characteristics and the fact that it does not depend on hollows of trees for nesting, since it constructs external nests, in addition to presenting very populous colonies (up to more than one hundred thousand individuals) (Almeida \& Laroca 1988), strong jaws, sharp teeth and highly defensive behavior that is quite efficient against natural enemies. These factors can contribute to guarantee adaptive success, but on the other hand reduce the possibility of beekeeping and exploitation of its products (Shackleton et al. 2015, Jaffé et al. 2016).

In the case of Plebeia aff. flavocincta, this bee also presents wide distribution and reproductive, survival and occupation success in diverse habitats. However, its strategies are different from $T$. spinipes, ranging from using camouflage to go unnoticed by predators, generalist foraging habits and using various types of nesting substrates, such as small cavities of trees, spaces in brick walls, fence posts and even cavities of dry and empty coconuts, in addition, it has a short interval of time to swarm (Martins et al. 2004, Witter et al. 2007, Silva et al. 2019). Due to its wide occurrence throughout the territory of Ceará, low defensiveness and good resilience, this species can be recommended for beginners in meliponiculture, even in urban areas.

In relation to the species distribution, some occur only in regions of Humid forest of the Crystalline Landscapes and Dry Forest of the Crystalline Landscapes, as is the case of M. flavolineata, C. aff. femorata, T. guianae and Nannotrigona sp. 1 and sp. 2, while M. mondury and $T$. recursa were only found in Humid Forest of the Sedimentary Landscapes and Dry Forest of the Sedimentary Landscapes. About $80 \%$ of the Ceará State is covered by caatinga, and the fact that these species were not found in the caatinga suggests dependence on specific climatic and environmental conditions of these mountain ranges and their surroundings, such as higher relative humidity, higher rainfall levels, lower temperatures, higher altitudes and vegetation typical of these locations (Tabarelii \& Santos 2004). For this reason, it is ill advised to transport and breed these species in areas with environmental characteristics different from those described previously, since it can impede the colony's survival.

The opposite is observed with M. subnitida, M. asilvai and M. mandacaia that were not found in any of the wet forest regions of the State. In the case of $M$. subnitida, this probably occurs because this species evolved in the caatinga and 
Table IV. List of meliponines species with occurrence recorded in the State of Ceará according to the literature. [1] Ducke 1907; [2] Ducke 1908; [3] Ducke 1910; [4] Gonçalves 1973; [5] Westerkamp et al. 2007; [6] Lima-Verde 2011; [7] Pedro 2014; [8] Mascena et al. 2017; [9] Oliveira et al. 2020; [10] Lima-Verde \& Freitas 2002; [11] Camargo \& Pedro 2013; [12] Nogueira et al. 2019a; [present study].

\begin{tabular}{|c|c|c|}
\hline Species recorded & Vernacular name & Source \\
\hline Camargoia cf. nordestina (Camargo, 1996) & Mombuca & {$[5 ; 7]$} \\
\hline Cephalotrigona aff. femorata (Smith, 1854) & Mombucão & Present study \\
\hline Cephalotrigona capitata (Smith, 1854) & Mombucão & {$[2 ; 3 ; 6 ; 7]$} \\
\hline Frieseomelitta doederleini (Friese, 1900) & Moça branca & {$[2 ; 3 ; 4 ; 6 ; 5 ; 7 ;$ present study $]$} \\
\hline Frieseomelitta francoi (Moure, 1946) & & {$[6]$} \\
\hline Frieseomelitta languida (Moure, 1990) & Mocinha preta & Present study \\
\hline Frieseomelitta varia (Lepeletier, 1836) & Marmelada & [2; 3; 4; 6; 5; present study] \\
\hline Geotrigona aequinoctialis (Ducke, 1925) & Mombuca & {$[2 ; 3 ; 7 ; 4]$} \\
\hline Lestrimelitta limao (Smith, 1863) & Limão & {$[2 ; 3,4 ; 5 ; 7]$} \\
\hline Lestrimelitta rufa (Friese, 1903) & Limão & [8] \\
\hline Lestrimelitta rufipes (Friese, 1903) & Limão & [7] \\
\hline Lestrimelitta tropica (Marchi \& Melo, 2006) & Limão & {$[4 ; 6 ; 7 ;$ present study] } \\
\hline Leurotrigona muelleri (Friese, 1900) & Lambe olhos & {$[3 ; 5]$} \\
\hline Melipona (Eomelipona) asilvai Moure, 1971 & Manduri & {$[5 ; 7 ;$ present study] } \\
\hline Melipona (Melikerria) quinquefasciata Lepeletier, 1836 & Uruçú do chão & {$[7 ; 10 ;$ present study] } \\
\hline Melipona (Michmelia) scutellaris Latreille, 1811 & Uruçú & {$[4 ; 5 ; 7]$} \\
\hline Melipona flavolineata (Friese, 1900) & Uruçú amarelo & [2; 3; 7; present study] \\
\hline Melipona mandacaia (Smith, 1863) & Mandaçaia & [4; 7; present study] \\
\hline Melipona marginata Lepeletier, 1836 & Manduri & {$[3 ; 4 ; 7]$} \\
\hline Melipona (Michmelia) mondury Smith, 1863 & Uruçu amarelo & Present study \\
\hline Melipona rufiventris (Lepeletier, 1836) & Uruçú amarelo & {$[2,3 ; 4 ; 6 ; 5]$} \\
\hline Melipona subnitida (Duck, 1910) & Jandaíra & {$[2 ; 3 ; 4 ; 5 ; 7 ;$ present study] } \\
\hline Nannotrigona punctata (Smith, 1854) & Camuengo & {$[5]$} \\
\hline Nannotrigona testaceicornis (Lepeletier, 1836) & Iraí & {$[2 ; 3]$} \\
\hline Oxytrigona tataira (Smith, 1863) & Tataíra & {$[3 ; 4 ; 5 ; 6 ;$ present study] } \\
\hline Paratrigona intermedia (Oliveira, Madella-Aurichio \& Freitas, 2020) & Jati do chão & [9] \\
\hline Paratrigona lineata (Lepeletier, 1836) & Jati da terra & [4; 7; present study] \\
\hline Partamona ailyae (Camargo, 1980) & Mombuca & [6; 7; present study] \\
\hline Partamona cupira (Smith, 1863) & Cupira & [2; 3; present study] \\
\hline Partamona aff. rustica (Pedro \& Camargo, 2003) & Cupira & Present study \\
\hline Partamona seridoensis (Pedro \& Camargo, 2003) & Cupira & [4; 7; present study] \\
\hline Partamona testacea (Klug, 1807) & Cupira & {$[4 ; 5 ; 7]$} \\
\hline Plebeia flavocincta (Cockerell, 1912) & Jati, mosquito & [6; 5; present study] \\
\hline Scaptotrigona bipunctata (Lepeletier, 1836) & Canudo & {$[2 ; 3 ; 4 ; 5 ; 7]$} \\
\hline Scaptotrigona aff. depilis (Moure, 1942) & Canudo & Present study \\
\hline Scaptotrigona postica (Latreille, 1807) & Canudo & [11; present study] \\
\hline Scaptotrigona tubiba (Smith, 1863) & Tubiba & {$[4 ; 5]$} \\
\hline Scaura cearensis (Nogueira, Santo Júnior, Oliveira \& Oliveira 2019) & Pegoncito & [12; present study] \\
\hline Tetragona dorsalis (Smith, 1854) & Borá & {$[2 ; 3 ; 7]$} \\
\hline Tetragonisca angustula (Latreille, 1811) & Jataí & [2; 3; present study] \\
\hline Trigona fulviventris (Guérin, 1844) & Cú de vaca & {$[6 ; 5]$} \\
\hline Trigona fuscipennis (Friese, 1900) & Sanharó & {$[2 ; 3 ; 4 ; 6 ; 5 ;$ present study $]$} \\
\hline Trigona guianae (Cockerell, 1910) & Cú de vaca & {$[2 ; 3 ; 7 ;$ present study $]$} \\
\hline Trigona pallens (Fabricius, 1798) & Olho de vidro & Present study \\
\hline Trigona recursa (Smith, 1863) & Vamos embora & [4; 7; este trabalho] \\
\hline Trigona spinipes (Fabricius, 1793) & Arapuá & {$[1 ; 2 ; 3,4 ; 6 ; 7 ;$ present study] } \\
\hline Trigonisca duckei (Friese, 1900) & Lambe olhos & {$[2,3 ; 7 ;$ present study $]$} \\
\hline Trigonisca aff. extrema (Albuquerque \& Camargo, 2007) & Lambe olhos & Present study \\
\hline Trigonisca pediculana (Fabricius, 1804) & Lambe olhos & {$[4 ; 6 ; 7]$} \\
\hline
\end{tabular}


is adapted to conditions of high temperature, low relative humidity and has a very close relation with the plants of this biome (Leal et al. 2003, Imperatriz-Fonseca et al. 2017). As in the wet mountains, the temperature remains around $20^{\circ} \mathrm{C}$ at night and there is high humidity during the rainy season, this should hinder the development of $M$. subnitida in these regions. Nevertheless, with the elevation of temperature in the Northeast due to climatic changes, these altitude refuges may become, in the future, areas with adequate conditions for conservation of the species (Carvalho et al. 2017, Jaffé et al. 2019).

In the case of Scaptotrigona, we found four species that showed distribution in the territory of Ceará from the regions of wet forest and dry forest, Inland Savannas and coastal vegetation complex and, in rare occasions, areas of caatinga. In addition, these species occur more frequently in areas of wet and dry forests and appear to be better developed and more productive in these regions, where beekeepers reported productivity of three liters of honey/ colony/year. The fact that these species also occur on the coast in more humid places, such as the municipality of Fortaleza and more frequently in mountains, suggests a certain dependence on areas with higher relative humidity. Although they are resilient species with good reproductive success, there are few breeders of these species in the caatinga area. More studies are required to evaluate the productive and adaptive performance of these species in environments similar to that of caatinga. In addition to providing bee products, Scaptotrigona species are also considered to be excellent potential pollinators for agricultural use (Bomfim et al. 2013).

In turn, M. scutellaris is a species which was already considered rare in many regions of the State more than 45 years ago (Gonçalves 1973). In this study, it was found only in meliponaries and the colonies were introduced from another state (Pernambuco). Despite the efforts made, it was not possible to find wild nests, which suggests that this species no longer exists in natural conditions in Ceará. Besides this, $M$. fasciculata was also introduced from another state (Maranhão) and has adapted well to the coastal region of Ceará. However, it has never been reported the natural occurrence of this species in the territory of Ceará, which raises a concern about competition with local species and the possibility of transmission of diseases and/or parasites to native populations as reported to the spillover infection of a Frieseomelitta varia colony by Pyemotes tritici mites from a Tetragonisca angustula colony brought from a different region (Menezes et al. 2009), and Deformed Wing Virus (DWV) from Apis mellifera to Melipona subnitida in NE Brazil (Souza et al. 2019).

Based on the richness of species found in this study and their distribution, it is clear to the stingless beekeepers that it is possible to diversify the species they breed, regardless of the region of the state they are and without the need to bring species that do not occur in areas similar to their breeding grounds. As the natural occurrence of some species is limited to some phytoecological units of the state, it is advisable that those interested in initiating meliponiculture activities and/or diversifying their beekeeping activities to choose species that occur naturally in these regions or occur in regions with similar environmental characteristics. This can help to avoid a series of ecological problems, from the non-adaptation of a species to a new place with different climatic and environmental characteristics, competition between introduced and native species for space and resources, extinction of native species until disease transmission for local native bee populations that may be caused 
by the uncontrolled transport of meliponine species from one region to another (Vollet Neto et al. 2018).

The review of studies on the stingless bee species already recorded in the State of Ceará, together with new occurrences described in this study showed that Ceará presents a rich meliponine biodiversity, since Brazil with its huge territorial extension and all its diverse conditions climatic and environmental conditions is home to 244 species of meliponines already validated plus other 89 new species to be described, totaling 333 species so far (Pedro 2014), with 49 (15.01\%) of them found in the territory of Ceará. Our data emphasize the need for detailed studies throughout the Brazilian territory to expand the knowledge about the diversity of this group of bees.

\section{CONCLUSIONS}

The fauna of meliponines in the State of Ceara is rich and diverse, and composed of at least 49 species, a greater number than previously reported.

Although meliponines occur all over Ceará, the natural distribution of the species is not homogeneous and is strongly linked to the environmental conditions of the phytoecological units of the state.

Species of meliponines once considered common in the state are threatened or locally extinct in the wild, being no longer possible to find them outside meliponaries. Urgent measures are needed to conserve the remaining species.

The high richness and wide distribution of meliponines in the State of Ceará indicates a good potential for the expansion of sustainable meliponiculture, and also the possibility of developing the activity in any region of the State.

\section{Acknowledgments}

We would like to thank the stingless beekeepers from Ceara who collaborated to this study, Prof. Favizia Freitas de Oliveira from the Universidade Federal da Bahia for the identification of bee specimens, Dr. Marcelo Freire Moro and Dr. Luiz Wilson Lima-Verde for help with description of the types of vegetation of Ceará, and Embrapa Meio-Norte through the project SEG 02.11.01.029.00.00. Breno M. Freitas is thankful to CNPq - Conselho Nacional de Desenvolvimento Científico e Tecnológico for a Research in Productivity Sponsorship (\#305126/2013-0). This study was financed in part by the Coordenação de Aperfeiçoamento de Pessoal de Nivel Superior - Brasil (CAPES) - Finance Code 001.

\section{REFERENCES}

ALMEIDA MC \& LAROCA S. 1988. Trigona spinipes (Apidae, Meliponinae): taxonomia, bionomia e relações tróficas em áreas restritas. Acta Biol Parana 17: 67-108.

ANDRADE-LIMA D. 1982. Present day forest refuges in Northeastern Brazil, In: Prance GT (Org). Biological diversification in the tropics. New York: University Press, p. 245-251.

BOMFIM IGA, BEZERRA ADM, NUNES AC, ARAGÃO FAZ \& FREITAS BM. 2014. Adaptive and foraging behavior of two stingless bee species (Apidae: Meliponini) in greenhouse mini watermelon pollination. Sociobiol 61: 502-509.

BOMFIM IGA, CRUZ DO, FREITAS BM \& ARAGÃO FAS. 2013. Polinização em melancia com e sem semente, Fortaleza: (Documentos / Embrapa Agroindústria Tropical, 168), 53 p.

BPBES/REBIPP. 2019. Relatório temático sobre Polinização, Polinizadores e Produção de Alimentos no Brasil. Wolowski M et al. (Org). 1a ed., São Carlos, SP: Editora Cubo, $184 \mathrm{p}$.

BRANDÃO RL \& FREITAS LCB. 2014. Geodiversidade do estado do Ceará. Fortaleza: CPRM, 214 p.

BRASIL. 2004. Resolução Conama no 364, de 17 de agosto de 2004 - Disciplina a utilização das abelhas silvestres nativas, bem como a implantação de meliponários. Publicação DOU no 158, de 17/08/2004.

CAMARGO JMF \& PEDRO SRM. 2013. Meliponini Lepeletier, 1836. In: Moure JS, Urban D and Melo GAR (Orgs). Catalogue of bees (Hymenoptera, Apoidea) in the Neotropical Region - online version. Available at_http:// www.moure.cria.org.br/catalogue. Accessed Mar/26/2019. 
CARVALHO AT \& ZANELLA FCV. 2017. Espécies de abelhas sem ferrão criadas no estado do Rio Grande do Norte. In: Imperatriz-Fonseca VL, Koedam D and Hrncir M (Org). A abelha jandaíra: no passado, presente e no futuro, Mossoró: EdUFERSA, p. 41-72.

CARVALHO AT ET AL. 2017. Distribuição geográfica atual da abelha jandaíra e previsões para sua distribuição futura. In: Imperatriz-Fonseca VL, Koedam D and Hrncir M (Org). A abelha jandaíra: no passado, presente e no futuro, Mossoró: EdUFERSA, p. 73-78.

CONTRERA FAL, MENEZES C \& VENTURIERI GC. 2011. New horizons on stingless bees beekeeping (Apidae, Meliponini). Rev Bras Zootec 40: 48-51.

COSTA-NETO DJ, VALADARES MS, SILVA-COSTA ES \& SOUTO JN. 2016. Levantamento da fauna de abelhas sem ferrão no estado do Tocantins. Acta Biol Catar 3: 138-148.

DUCKE A. 1907. Contribution à la connaissance de la faune hyménoptérologique du Nord-Est du Bresil. Rev Entomol 26: 73-96.

DUCKE A. 1908. Contribution à la connaissance de la faune hyménoptérologique du Nord-Est du Brésil: I: Hyménoptères récoltés dans l'Etat de Ceará em 1908. Rev Entomol 27: 57-81.

DUCKE A. 1910. Explorações botânicas e entomológicas no Estado do Ceará. Rev Trim Inst Cear 24: 3-61.

FELIX JA. 2015. Perfil zootécnico da meliponicultura no Estado do Ceará, Brasil. Dissertação (Programa de pósgraduação em Zootecnia). Fortaleza - CE: Universidade Federal do Ceará (UFC), 79 p. (Unpublished).

FREITAS BM, IMPERATRIZ-FONSECA VL, MEDINA LM, KLEINERT AMP, GALETTO L, NATES-PARRA G \& QUEZADA-EUÁN JJG. 2009. Diversity, threats and conservation of native bees in the Neotropics. Apidologie 40: 332-346.

GONÇALVES JA. 1973. Ocorrência e abundância de abelhas indígenas no Estado do Ceará (Brasil). Bol Cear Agron 14: 1-13.

IBGE - INSTITUTO BRASILEIRO DE GEOGRAFIA E ESTATÍSTICA. 2004. Mapa de biomas do Brasil: primeira aproximação. Rio de Janeiro: IBGE.

IMPERATRIZ-FONSECA VL, CANHOS DAL, ALVES DA \& SARAIVA AM. 2012. Polinizadores no Brasil: Contribuição e perspectivas para a biodiversidade, uso sustentável, conservação e serviços ambientais, São Paulo: EDUSP, 488 p.

IMPERATRIZ-FONSECA VL, KOEDAM D \& HRNCIR M. 2017. A abelha jandaíra: no passado, presente e no futuro, Mossoró: EdUFERSA, 254 p.
IPBES. 2016. Summary for policymakers of the assessment report of the Intergovernmental Science-Policy Platform on Biodiversity and Ecosystem Services on pollinators, pollination and food production. In: Potts et al. 2016 (Ed). Secretariat of the Intergovernmental SciencePolicy Platform on Biodiversity and Ecosystem Services. Germany: Bonn, $36 \mathrm{p}$.

JAFFÉ R ET AL. 2015. Bees for Development: Brazilian Survey Reveals How to Optimize Stingless Beekeeping. PLOS ONE 10: 0121-157.

JAFFÉ R, CASTILLA A, POPE N, IMPERATRIZ-FONSECA VL, METZGER JP, ARIAS MC \& JHA S. 2016. Landscape genetics of a tropical rescue pollinator. Conserv Genet 17: 267-278.

JAFFÉ R ET AL. 2019. Landscape genomics to the rescue of a tropical bee threatened by habitat loss and climate change. Evol Applic 12: 1-14.

KERR WE, CARVALHO GA, SILVA AC \& ASSIS MGP. 2001. Aspectos Poucos Mencionados da Biodiversidade Amazônica. Parc Estrat 12: 20-41.

LEAL IR, TABARELLI M \& SILVA JMC. 2003. Ecologia e Conservação da Caatinga, Recife: Ed. Universitária da UFPE, $822 \mathrm{p}$.

LIMA-VERDE LW. 2011. Recursos melissofaunísticos do maciço de Baturité, Ceará, Brasil - Diversidade e potencialidade Zootecnica. Tese (Programa de Doutorado Integrado em Zootecnia - UFC/UFPB/UFRPE), Fortaleza -CE, 215 p.

LIMA-VERDE LW \& FREITAS BM. 2002. Occurrence and biogeographic aspects of Melipona quinquefasciata in NE Brazil (Hymenoptera, Apidae). Braz J Biol 62: 479-486.

LIMA-VERDE LW, LOIOLA MIB \& FREITAS BM. 2014. Angiosperm flora used by meliponine guilds (Apidae, Meliponina) occurring at rainforest edges in the state of Ceará, Brazil. An Acad Bras Cienc 86: 1395-1409.

LIMA-VERDE LW, PACHECO FILHO AJS \& FREITAS BM. 2020. Stingless bee (Apidae, Meliponini) guilds occurring in the immediate edges of forest fragments of the Baturite Massif, State of Ceará, Brazil. An Acad Bras Cienc 92: e20181303.

MADELLA-AURICCHIO CR. 2018. Efeitos da agricultura intensiva da soja e perda de hábitat nas assembleias de abelhas, nordeste do Brasil. Tese (Programa de Pós-Graduação em Ecologia e Recursos Naturais). Fortaleza - CE: Universidade Federal do Ceará (UFC), 81 p. (Unpublished).

MAGALHÃES TL \& VENTURIERI GC. 2010. Aspectos Econômicos da Criação de Abelhas Indigenas Sem Ferrão (Apidae: 
Meliponini) no Nordeste Paraense. Belém: (Documentos / Embrapa Amazônia Oriental, 364), 36 p.

MANTOVANI W. 2007. Conservação de biodiversidade: Importância das serras úmidas no nordeste semiárido brasileiro. In: Oliveira TS and Araújo FS (Org). Diversidade e Conservação da Biota na Serra de Baturité, Ceará, Fortaleza: Edições UFC, COELCE, p. 2-13.

MARTINS CF, CORTOPASSI-LAURINO M, KOEDAM D \& IMPERATRIZFONSECA VL. 2004. Tree species used for nidification by stingless bees in the Brazilian caatinga (Seridó, PB; João Câmara, RN). Biot Neotr 4(2).

MASCENA VM, NOGUEIRA DS, SILVA CM \& FREITAS BM. 2017. First Record of the Stingless Bee Lestrimelitta rufa (Friese) (Hymenoptera: Apidae: Meliponini) in NE Brazil and its Cleptobiotic Behavior. Sociobiol 64: 359-362.

MENEZES C, COLETTO-SILVA A, GAZETA GS \& KERR WE. 2009. Infestation by Pyemotes tritici (Acari, Pyemotidae) causes death of stingless bee colonies (Hymenoptera: Meliponina). Genet Mol Res 8: 630-634.

MORO MF, MACEDO MB, MOURA-FÉ MM, CASTRO ASF \& COSTA RC. 2015. Vegetação, unidades fitoecológicas e diversidade paisagística do estado do Ceará. Rodrig 66: 717-743.

NOGUEIRA DS, SANTOS JÚNIOR JE, OLIVEIRA FF \& OLIVEIRA ML. 2019a. Review of Scaura Schwarz, 1938 (Hymenoptera: Apidae: Meliponini). Zootaxa 4712: 451-496.

NOGUEIRA DS, TEIXEIRA JSG, MAHLMANN T, OLIVEIRA ML \& ROUBIK DW. 2019b. Geometric morphometrics of wing venation to differentiate new species of Scaura Schwarz populations (Hymenoptera: Apidae: Meliponini). Sci Plen 15: 1-9.

OLIVEIRA FF, MADELLA-AURICHIO CR \& FREITAS BM. 2020. A new species of Paratrigona Schwarz, 1938 from Northeast Brazil and notes on the type material of Melipona lineata Lepeletier, 1836 (Hymenoptera: Anthophila: Apidae). J Nat Hist 54: 1637-1659.

PEDRO SRM. 2014. The Stingless Bee Fauna In Brazil (Hymenoptera: Apidae). Sociobiol 61: 348-354.

POTTS SG, BIESMEIJER JC, KREMEN C, NEUMANN P, SCHWEIGER O \& KUNIN WE. 2010. Global pollinator declines: trends, impacts and drivers. Trends Ecol Evol 25: 345-353.

RIBEIRO-SILVA S, MEDEIROS MD, GOMES BM, SEIXAS ENC \& SILVA MAP. 2012. Angiosperms from the Araripe National Forest, Ceará, Brazil. Chec Lis 8: 744-751.

ROUBIK DW. 1989. Ecology and natural history of tropical bees. New York: Cambridge University Press, 514 p.

ROUBIK DW. 2018. 100 Species of Meliponines (Apidae: Meliponini) in a Parcel of Western Amazonian Forest at
Yasuní Biosphere Reserve, Ecuador. In: Vit P, Pedro S and Roubik D (Eds) Pot-Pollen in Stingless Bee Melittology. Springer: Cham, p. 189-206.

ROUBIK DW \& MORENO PATIÑO JE. 2018. The Stingless Honey Bees (Apidae, Apinae: Meliponini) in Panama and Pollination Ecology from Pollen Analysis. In: Vit P, Pedro S and Roubik D (Eds) Pot-Pollen in Stingless Bee Melittology. Springer: Cham, p. 47-66.

SAKAGAMI SF, LAROCA S \& MOURE JS. 1967. Wild bee biocenotics in São José dos Pinhais (PR), South Brazil. Preliminary report. J Facul Sci Hokkaido Univ Zool 16: 253-291.

SANTOS AMM, CAVALCANTI DR, SILVA JMC \& TABARELLI M. 2007. Biogeographical relationships in north-eastern Brazil. J Biogeogr 34: 437-446.

SHACKLETON K, TOUFAILIA HA, BALFOUR NJ, NASCIMENTO FS, ALVES DA \& RATNIEKS FLW. 2015. Appetite for selfdestruction: suicidal biting as a nest defense strategy in Trigona stingless bees. Behav Ecol Sociobiol 69: 273-281.

SILVA JG, MENESES HM \& FREITAS BM. 2019. Foraging behavior of the small-sized stingless bee Plebeia aff. flavocincta. Rev Ciênc Agron 50: 484-492.

SOUZA BA, CARVALHO CAL, ALVES RMO, DIAS CS \& CLARTON L. 2009. Munduri (Melipona asilvai): a abelha sestrosa. Cruz das Almas: Universidade Federal do Recôncavo da Bahia, $46 \mathrm{p}$.

SOUZA FS, KEVILL J, CORREIA-OLIVEIRA ME, CARVALHO CAL \& MARTIN SJ. 2019 Occurence of deformed wing virus variants in the stingless bee Melipona subnitida and honey bee Apis mellifera populations in Brazil. J Gen Virol 100(2): 1-6.

TABARELII M \& SANTOS MMA. 2004. Uma breve descrição sobre a história natural dos brejos nordestinos. In: Porto KC, Cabral JJP and Tabarelii M. Brejos de altitude em Pernambuco e Paraíba: história natural, ecologia e conservação. Brasília: Ministério do Meio Ambiente, p. 111-122.

THORNTHWAITE CW. 1948. An approach toward a rational classification of climate. Geogr Rev 38(1).

VENTURIERI GC. 2009. The impact of forest exploitation on Amazonian stingless bees (Apidae, Meliponini). Genet Mol Res 8: 684-689.

YAMAMOTO DY, AKATSU IP \& SOARES AEE. 2007. Quantificação da produção do mel de Scaptotrigona aff. depilis (Hymenoptera, Apidae, Apinae) do município de Luiz Antônio, São Paulo, Brasil. Biosci J 23: 89-93. 
VIT P, PEDRO SRM, MAZA F, RAMÍREZ VM \& FRISONE V. (2018) Diversity of Stingless Bees in Ecuador, Pot-Pollen Standards, and Meliponiculture Fostering a Living Museum Meliponini of the World. In: Vit P, Pedro S and Roubik D. (eds) Pot-Pollen in Stingless Bee Melittology. Springer: Cham. p. 207-227.

VOLLET NETO A, BLOCHTEIN B, VIANA B, SANTOS CF, MENEZES C, SILVA PN, JAFFÉ R \& AMOEDO S. 2018. Desafios e recomendações para o manejo e o transporte de Polinizadores, São Paulo: A.B.E.L.H.A., 100 p.

WESTERKAMP C, RIBEIRO MF, LIMA-VERDE LW, DELPRETE PG, ZANELLA F \& FREITAS BM. 2007. Adolfo Ducke e as abelhas (Hymenoptera, Apoidea) da Serra de Baturité, CE. In: Oliveira TS and Araújo FS. (Org.). Diversidade e Conservação da Biota na Serra de Baturité, Ceará. Fortaleza: Edições UFC, COELCE, p. 273-292.

WITTER S, BLOCHTEIN B, ANDRADE F, WOLFF LF \& IMPERATRIZFONSECA VL. 2007. Meliponicultura no Rio Grande do Sul: Contribuição sobre a biologia e conservação de Plebeia nigriceps (Friese, 1901) (Apidae, Meliponini). Biosci J 23: 134-140.

\section{How to cite}

FELIX JA \& FREITAS BM. 2021. Richness and distribution of the meliponine fauna (Hymenoptera: Apidae: Meliponini) in the State of Ceará, Brazil. An Acad Bras Cienc 93: e20190767. DOI 10.1590/0001-3765202120190767.
Manuscript received on July 09, 2019;

accepted for publication on October 25, 2019

\section{JÂNIO A. FELIX}

https://orcid.org/0000-0003-0734-7392

\section{BRENO M. FREITAS}

https://orcid.org/0000-0002-9932-2207

Universidade Federal do Ceará, Laboratório de Abelhas, Departamento de Zootecnia, Centro de Ciências Agrárias, Bloco 814, Av. Mister Hull, s/n, 60356-000 Fortaleza, CE, Brazil

Correspondence to: Jânio A. Felix

E-mail: janiozootecnia@yahoo.com.br

\section{Author contributions}

JAF and BMF conceived the project, designed the study, reviewed the literature and wrote the manuscript. JAF made the field trips and data collection. BMF obtained the financial support for the study and supervised the project. The authors declare that they have no conflict of interest.

\section{(cc) BY}

